\title{
THINK-PAIR-SQUARE LEARNING: IMPROVING STUDENT'S COLLABORATIVE SKILLS AND COGNITIVE LEARNING OUTCOME ON ANIMAL DIVERSITY COURSE
}

\author{
Mustafa Ainul Yaqin 1,", Sri Endah Indriwati², and Herawati Susilo \\ ${ }^{1}$ Postgraduate-Biology Education, State University of Malang, Malang, East Java, Indonesia \\ ${ }^{2}$ Biology Department, State University of Malang, Malang, East Java, Indonesia \\ *Corresponding email: mustafaainul226@gmail.com
}

\begin{abstract}
Empowering collaborative skills and optimizing learning outcomes are essential goals in every course. The aim of this study was to determine the effect of Think-Pair-Square (TPS) learning model on student collaborative skills and their cognitive learning outcomes. This study was Lesson-Study-based Classroom Action Research (CAR) carried out in two cycles. The subjects of this study consisted of 32 students who took Animal Diversity course. The CAR consisted of four phases i.e. planning, action, observation, and reflection. At the action phase, LS was conducted and consist of Plan, Do, and See. The instruments used were LS observation sheet, collaborative observation sheet, and cognitive test. The observation and test results of the both cycles were calculated and compared each other. There were improvements in the both student's collaborative skills and cognitive learning outcome as high as 14\% and 7.56, respectively. Therefore, TPS model can strengthen the student's collaborative skills and cognitive learning outcome.
\end{abstract}

Keywords: cognitive learning outcome; collaborative skills; Think-Pair-Square

\section{INTRODUCTION}

Education is a process that facilitates a person or group of people to gain knowledge, skills, and attitudes. Education can be managed in formal or informal setting. Formal education is divided into several levels, namely early childhood education and kindergarten, elementary school, secondary school, and higher education. Some levels of formal education can be experienced in various educational institutions, both public and private.

The purpose of various educational institutions in carrying out the process of education is to develop the nation intellectual life. By achieving the goal, the community can build a nation with good moral through education. To meet these objectives, not only does the learning process need to emphasize the concept understanding which is reflected in learning outcomes (Fauzi, 2013; Sukmawati, Ramadani, Fauzi, \& Corebima, 2015), but it also should ensure the empowerment of skills needed in $21^{\text {st }}$ century era, such as metacognition (Ramadani, Fauzi, Sukmawati,
\& Corebima, 2015), critical thinking skills, and collaborative skills (Ladd et al., 2014).

Collaboration is one of social interaction form in society. Thus, the skills needed in the interaction must be possessed by students as they graduated (Huang et al., 2010; Ouellet, Sabbagh, Bergeron, Mayer, \& St-Onge, 2016). Consequently, the efforts in empowering collaborative skills is essential. One of the learning conditions support the efforts is by setting the students to face some communal problems.

However, based on the observation results toward B class students in 2016 academic year of the State University of Malang on animal biodiversity course on September 30, 2017, the ability of students during working in their teamwork was relatively limited. Yet the students solved the problem given without any discussion. This evidence indicated that the students' collaborative skills were not empowered yet. These skills belong to social behavior for students in which important to be developed in their social life. Thus, it is necessary to design the learning which develop 
the skills through observing and improving the learning process itself.

Problems that arise in the learning process, including problem in empowering some important skills, is a condition that must be solved by educators. The effort to overcome this kind of learning problem is aimed to increase the learning process. In overcoming various problems that arise, various ways can be used as solutions to solving the problem. Various solutions have been reported could solve learning problem in biology learning, such as through the development of learning media or learning source (Fauzi, 2017; Widiansyah, Indriwati, Munzil, \& Fauzi, 2018), the use of model organisms (Fauzi \& Corebima, 2016c, 2016a, 2016b), the application of research activities in the learning process (Fauzi, Corebima, \& Zubaidah, 2016; Fauzi \& Ramadani, 2017), as well as the application of cooperative learning (Fauzi, 2013; Ramadani et al., 2015).

Cooperative learning is learning model that classifies students with the aim of creating a learning condition that effectively facilitate the improvement of social skills (Lavasani, Afzali, \& Afzali, 2011; Lie, 2005; Strebe, 2013; Suprijono, 2009). The advantages of implementing cooperative learning are to give opportunities to students to express and discuss the learning material. The cooperative learning is a learning form that covering all types of group learning. Through cooperative learning, the teacher assigns tasks and questions and provides materials and design information to help students to solve the problem.

Think-Pair-Square (TPS) learning model is the modification of Think Pair Share model that developed by Spencer Kagan (Fisher \& Frey, 2014; Lapp \& Moss, 2012; Strebe, 2013). TPS provides students the opportunity to work on their own and work with the others. The syntax of TPS is basically similar as Think Pair Share. First, the students think for themselves. Second, the students discuss with their partner. Finally, the students make a group that consists of four members to solve the existing problems. Due to the possibility of conduct problem solving activities during learning process, TPS probably can facilitate the improvement of students' collabarotaive skills. Some previous studies used this cooperative learning as the alternative solution to solve the problem in the learning process (Erra, Portnova, \& Scanniello, 2010; Erra \& Scanniello, 2011; Karyawati, Murda, \&
Widiana, 2014; Magsino, 2014; Scanniello \& Erra, 2014; Tahueyo, Martawijaya, \& Azis, 2013)

Beside collaborative skills, learning outcomes are one of the goals to be achieved in the learning process (Buku, Mite, Fauzi, Widiansyah, \& Anugerah, 2015; Fauzi, 2013; Ramadani et al., 2015). The results achieved by the students give an information about the position of their academic success compared to others. Learning outcomes can be measured through tests that are often known as learning result tests. Moreover, the result of the test can reveal the quality of the learning.

Previous reports have reported the potency of implementing TPS in classroom learning. Several previous studies informed the implementation of TPS can improve student comprehension of learning material (Bennett, 2012; Hermiati, 2017). Several other reports have reported that the application of this learning model may improve critical thinking skills (Sumaryati \& Sumarmo, 2013), creative thinking skills (Utami, 2014), communication skills (Talat \& Chaudhry, 2014), and learning outcomes (Isharyadi, 2015; Januartini, Agustini, \& Sindu, 2016; Karyawati et al., 2014; Tahueyo et al., 2013), beside also have impact on students' participation (Zainollah, 2014) and students' motivation (Januartini et al., 2016) during learning process. However, no reports have reported the application of TPS as a solution to improve learning outcomes as well as students' collaborative skills. In fact, the stages of the learning process in this model facilitate students to empower their collaborative skills.

Based on the problems found in the Animal Biodiversity Class and based on the potency of TPS model in empowering the learning outcomes and collaborative skills, classroom action research (CAR) would be conducted in the B class that followed Animal Biodiversity course. Moreover, Several recent CAR reports have informed that LS-based CAR implementation can provide the learning process more optimally (Buku et al., 2015; Mustofa et al., 2016). Therefore, in order to improve the learning process, lesson study would also be conducted on this CAR

\section{METHOD}

This study is a Lesson Study basedClassroom Action Research (LS-based CAR). 
The research was conducted in the Department of Biology Education, the State University of Malang in Animal Biodiversity Course. The research subjects were B class students in 2016 academic year. This CAR consists of two cycles, the first cycle consists of three meetings, while the second cycle consists of four meetings. The course material taught in cycle 1 was "Low Cordata", while in cycle 2 was "Mammalia".

Each CAR cycle consists of four phases, namely planning, action, observation, and reflection. Meanwhile, LS was composed of three phases, namely plan, do, and see. In the planning phase, the lecturers collaborate with LS members to design the lecture plan and arrange the lecture plan at the next meeting. The lecture plan is focused on the studentcentered learning process. Learning model that was planned in this research was TPS. Learning phase in this model was: 1) "Thinking", the lecturer asks a question or issue related to the lesson and asks the students to think independently to solve the issue; 2) "Pairing", the lecturer asks the students to pair up and discuss what they think. Interactions during this period can facilitate the students to share their answers to their teammate; 3) "Square", in this final step, the lecturer asks both of partners to meet again in a group of four. The students have the opportunity to share their work in a group of four.

In the do phase, there were two main activities, namely: (1) learning activities conducted by lecturers that practice the lesson plans that have been prepared together, and (2) observation activities conducted by other LS members. At the see phase, LS members review the lecture process that has been implemented and the proposed improvement of the next meeting.

The research instruments used include of; 1) observation sheets of LS activities; 2) collaboration skill observation sheet; and 3) cognitive tests. The second and third instruments were used as a means of collecting data on collaborative skills and student learning outcomes. Therefore, the collaborative skills data were obtained from observation result by the observer and cognitive learning outcomes data were obtained from the test result. Some of the indicators used in scoring collaborative skills, were 1) positive interdependence; 2) face-to-face promotive interaction; 3 ) individual accountability and personal responsibility; 4) interpersonal and small group skills; and 5) group processing. The results of the collaborative skill assessment observation were analyzed by using Formula 1 (Purwanto, 2014).

$N p=(R / S M) \times 100 \%$

Information:

$\mathrm{Np} \quad$ : percentage rate of achievement collaborative skills

$\mathrm{R} \quad$ : the total score of all obtained points

SM : the maximum score of the total points

At the end of CAR cycle, both collaborative skill and cognitive learning outcomes were analyzed to know the improvement of those parameters from cycle 1 to cycle 2 .

\section{RESULTS AND DISCUSSION}

The calculation of students' collaborative skill at Cycle 1 and Cycle 2 can be seen in Table 1 and Table 2.

Table 1. The average score of all the collaboration skills in cycle 1 and cycle 2

\begin{tabular}{cccc}
\hline Cycles & $\begin{array}{c}\text { Average } \\
(\boldsymbol{\%})\end{array}$ & Deviation & Conclusion \\
\hline 1 & 79 & - & - \\
2 & 92 & 14 & Increasing \\
\hline
\end{tabular}

Table 2. The calculation results of collaborative skill in cycles 1 and 2

\begin{tabular}{lll}
\hline \multicolumn{1}{c}{ Collaboration skill } & $\begin{array}{l}\text { Cycle } \\
\mathbf{1}(\boldsymbol{\%})\end{array}$ & $\begin{array}{l}\text { Cycle } \\
\mathbf{2 ( \% )}\end{array}$ \\
\hline Positif interdependence & 80 & 87 \\
$\begin{array}{l}\text { Face-to-face promotive } \\
\text { interaction }\end{array}$ & 86 & 96 \\
$\begin{array}{l}\text { Individual accountability and } \\
\text { personal responsibility }\end{array}$ & 88 & 96 \\
$\begin{array}{l}\text { Interpersonal and small group } \\
\text { skills }\end{array}$ & 80 & 95 \\
\begin{tabular}{l} 
Group processing \\
\hline
\end{tabular} & 61 & 88 \\
\hline
\end{tabular}

Based on Table 1, student's collaborative skills scores increased by $14 \%$ from cycle 1 to cycle 2. Furthermore, based on Table 2, improvement of students' collaborative skills occurred in each indicator. Each indicator has increased more than 5\% and the indicator "group processing" is an indicator that the greatest increase, from $61 \%$ to $88 \%$.

The results of this study are in line with some previous research reports that also used cooperative learning model (Ding et al., 2014; Talat \& Chaudhry, 2014). The improvement of 
collaborative skills through cooperative learning due to in this learning students are divided into small groups, whereas each group member has different abilities. Each member of the group is responsible not only for learning the material but also learning to help friends in one group.

Related to the implementation of TPS, the increasing of collaborative skills from cycle 1 to cycle 2 shows that the TPS learning model could empower the students' skills in the collaborating with each other. In collaborative skills, several skills related to the collaboration process among students is required. In connection with this, several previous reports reported that the application of TPS learning model is able to empower and improve students communication skills (Talat \& Chaudhry, 2014; Zainollah, 2014), students' social skills (Apriliyani, Wasis, \& Supardi, 2015), as well as speaking skills (Lubis, 2014).

If TPS is analyzed in more depth, in this learning model, students' collaborative skills can be raised at every stage of the TPS learning model. The first stage, Think, is aimed to introduce the concept of matter in the presence of a given phenomenon. Moreover, at this stage, students will think individually about an existing problem since it can open selfawareness in solving a problem by working together. At the stage of Pair, students work in pair to solve problems, in which case a paired discussion will appear. In the last stage of the Square, 2 pairs of groups will merge into one group to discuss the existing problems so that the discussion will proceed actively (Fisher \& Frey, 2014; Lapp \& Moss, 2012; Strebe, 2013).

Furthermore, TPS learning model is a model of cooperative learning that requires students to work together in solving a problem. TPS learning model also gives students the opportunity to work on their own and work with others and optimize student participation. Moreover, The TPS model provides at least eight times more opportunities for each student to be recognized and show their participation to others. This explanation is in line with Anas, Atmoko, \& Suyono, (2012) that explained the TPS learning model allows the students to work individually or in groups as well as optimize student participation. This condition is essential to empower collaborative skills. Moreover, this learning model has also given more opportunities to each student to be recognized and show their participation to others (Lie, 2005).

In the second parameter, students' cognitive learning outcomes were also improving from cycle 1 to cycle 2 . The improvement of students' cognitive learning outcome as high as 7.56. The data on students' cognitive learning outcomes are presented in Table 3 . The results of this study that indicate TPS could improve students' learning outcome are in line with some previous reports (Isharyadi, 2015; Januartini et al., 2016; Karyawati et al., 2014; Tahueyo et al., 2013).

Table. 3 The average result of cognitive learning in cycle 1 and cycle 2

\begin{tabular}{cccc}
\hline Cycles & $\begin{array}{c}\text { Avarage } \\
(\boldsymbol{\%})\end{array}$ & Deviation & Conclusion \\
\hline 1 & 77.94 & - & - \\
2 & 87.50 & 7.56 & Increasing \\
\hline
\end{tabular}

Learning experiences that occur in a learning process will affect the achievement of student learning outcomes (Sudjana, 2017). In this regard, the use of appropriate learning models will have a positive impact on student learning outcomes. These positive results are often caused by the selection of instructional models that lead students to be active during learning (Savitri \& Wahyuni, 2013). Related to the statement, a previous study has informed the implementation of TPS could facilitate students to more active during the learning process in class (Zainollah, 2014). The reason, the implementation TPS learning model will give students the opportunity to discuss possible ideas and the solutions for a particular problem through discussions activities (Scanniello \& Erra, 2014).

Related to its syntax, TPS learning model designed a paired group consisting of 2 students and each group will discuss and solve the given problem (Januartini et al., 2016). From this activity, the quality of learning will improve due to students will more engaged with learning process through interviews, discussion, as well as question and answer activity (Suyanto, 2008). Furthermore, through TPS learning model, it provides an advantage to students to discuss their ideas and provide an opportunity to understand problem solving in different ways. All of these activities will facilitate students to better understand the concepts being studied. 
Collaborative skills and cognitive learning outcomes are two essential components and need to be empowered during learning. If students are not getting an optimal achievement on one or both of these parameters, it may be caused by a less precise learning process. Therefore, the selection of appropriate learning models is one key to success in facilitating students to achieve optimum competence. One of the appropriate learning models, in accordance with the results of this study, is TPS.

\section{CONCLUSION}

TPS is one of the learning models that potentially empowers collaborative skills and cognitive learning outcomes. Through this research, this potential was proven. Students' collaborative skills and cognitive learning outcomes of students have improved after class B students at Biology Department, State University of Malang followed Animal Biodiversity course which applying TPS learning. Based on these findings, it is recommended for Biology educators to apply the TPS learning model as one of the learning alternatives in their class.

\section{REFERENCES}

Anas, M., Atmoko, T., \& Suyono. (2012). Eksperimentasi model pembelajaran think pair share modifikasi penemuan terbimbing berbantuan Microsoft Power Point pada kedisiplinan belajar. Jurnal Pendidikan, 259-267. Retrieved from http://download.portalgaruda.org/article.p hp? article $=106933 \&$ val $=4039$

Apriliyani, B. F., Wasis, \& Supardi, Z. A. I. (2015). Pengembangan perangkat pembelajarna fisika berorientasi model pembelajaran kooperatif think pair square dalam meningkatkan keterampilan sosial dan ketuntasan belajar siswa. Pendidikan Sains Pascasarjana Universitas Negeri Surabaya, 4(2), 579-590. Retrieved from https://journal.unesa.ac.id/index.php/jpps/ article/download/466/313

Bennett, S. M. smbenne mail usf edu. (2012). Social studies textbooks for pre-service elementary teachers: Implications for literacy and ELL instruction. Journal of Social Studies Education Research, 3(1), 65-94. Retrieved from https://login. ezproxy.utas.edu.au/login?url=http://searc h.ebscohost.com/login.aspx?direct=true \& $\mathrm{db}=$ eue $\& \mathrm{AN}=90496624 \&$ site $=$ eds-live

Buku, M. N. I., Mite, Y., Fauzi, A., Widiansyah, A. T., \& Anugerah, D. Y. (2015). Penerapan pembelajaran cooperative script berbasis lesson study sebagai upaya peningkatan keaktifan lisan dan kecakapan sosial mahasiswa SI Pendidikan Biologi matakuliah strategi belajar mengajar. In Proceedings of the 2nd Seminar \& Workshop Nasional Biologi, IPA, dan Pembelajarannya FMIPA UM (pp. 603-606). Malang: Biologi FMIPA UM.

Ding, X., Zhao, L., Chu, H., Tong, N., Ni, C., $\mathrm{Hu}, \mathrm{Z}$., \& Zhang, Z. (2014). Assessing the effectiveness of problem-based ;earning of Preventive Medicine Education in China. Scientific Reports, 4(5126), 1-5. https://doi.org/10.1038/srep05126

Erra, U., Portnova, A., \& Scanniello, G. (2010). Comparing two communication media in use case modeling: Results from a controlled experiment. In Proceedings of the 2010 ACM-IEEE International Symposium on Empirical Software Engineering and Measurement. BolzanoBosen. https://doi.org/10.1145/1852786.1 852854

Erra, U., \& Scanniello, G. (2011). Assessing think-pair-square in distributed modeling of use case diagrams. In Proceedings - $1 s t$ International Workshop on Empirical Requirements Engineering, EmpiRE 2011 (pp. 77-84). Trento. https://doi.org/10. 1109/EmpiRE.2011.6046249

Fauzi, A. (2013). Pengaruh kemampuan akademik terhadap keterampilan metakognitif, hasil belajar biologi, dan retensi siswa SMA Kelas $X$ dengan penerapan strategi pembelajaran cooperative script di Malang. Universitas Negeri Malang. https://doi.org/10.13140/ RG.2.2.24659.99363

Fauzi, A. (2017). Analisis filogeni Tarsius tarsier form Buton dengan beberapa spesies tarsius dari Sulawesi Tengah, Sumatera-Kalimantan, dan Filipina atas dasar Gen MT-CO2 sebagai bahan pengembangan buku panduan penelitian Mata Kuliah Genetika II di Universitas Negeri Mal. Universitas Negeri Malang, Indonesia.

Fauzi, A., \& Corebima, A. D. (2016a). 
Fenomena gagal berpisah, epistasis, dan nisbah kelamin pada Drosophila melanogaster. In Seminar Nasional Biologi 2016 (pp. 283-288). Surabaya: Universitas Negeri Surabaya.

Fauzi, A., \& Corebima, A. D. (2016b). Pemanfataan Drosophila melanogaster sebagai organisme model dalam mempelajari Hukum Pewarisan Mendel. In Seminar Nasional Biologi 2016 (pp. 372-377). Surabaya: Universitas Negeri Surabaya.

Fauzi, A., \& Corebima, A. D. (2016c). Pemanfataan Drosophila melanogaster sebagai organisme model dalam mengungkap berbagai fenomena penyimpangan rasio Mendel. In Seminar Nasional Biologi 2016 (pp. 278-282). Surabaya: Universitas Negeri Surabaya.

Fauzi, A., Corebima, A. D., \& Zubaidah, S. (2016). The utilization of ferns as a model organism for studying natural polyploidization concept in genetics course. In International Conference on Education (pp. 51-58). Malang: Universitas Negeri Malang. Retrieved from http://pasca.um.ac.id/conferences/index.php/ice/article/download/11/8

Fauzi, A., \& Ramadani, S. D. (2017). Learning the genetics concepts through project activities using Drosophila melanogaster: a qualitative descriptive study. JPBI (Jurnal Pendidikan Biologi Indonesia), 3(3), 238-247. https://doi.org/10.22219/ jpbi.v3i3.4540

Fisher, D., \& Frey, N. (2014). Close reading and writing from sources. Newark: International Reading Association.

Hermiati. (2017). The effectiveness of thinkpair-square (TPS ) strategy in teaching students' listening comprehension at the second grade in SMA Negeri 3 Sidrap. Alauddin State Islamic University of Makassar. Retrieved from http://repositori. uin-alauddin.ac.id/7462/1/HERMIATIS.p df

Huang, D., Leon, S., Hodson, C., La, D., Obregon, T. N., \& Rivera, G. (2010). Preparing students for the 21st century: Exploring the effect of afterschool participation on students' collaboration skills, oral communication skills, and selfefficacy. Los Angeles. https://doi.org/10. 1037/e642072011-001

Isharyadi, R. (2015). Penerapan model pembelajaran kooperatif pendekatan struktural think pair square untuk meningkatkan hasil belajar matematika siswa. Jurnal Ilmiah Edu Research, 4(1), 71-78. Retrieved from http://ejournal.upp.ac.id/index.php/EDU/article/v iewFile/783/622

Januartini, P. D., Agustini, K., \& Sindu, I. G. P. (2016). Studi komparatif model pembelajaran think pair square dan think pair share terhadap motivasi dan hasil belajar siswa mapel TIK kelas X SMA N 1 Sukasada. Jurnal Pendidikan Teknologi Dan Kejuruan, 13(2), 148-160. https://doi.org/10.23887/jptk.v13i2.8523

Karyawati, N. K., Murda, I. N., \& Widiana, I. W. (2014). Pengaruh model pembelajaran kooperatif tipe think pair square berbantuan kartu kerja terhadap hasil belajar matematika. MIMBAR PGSD Undiksha, 2(1). Retrieved from https://ejournal.undiksha.ac.id/index.php/J JPGSD/article/view/2211

Ladd, G. W., Kochenderfer-Ladd, B., Visconti, K. J., Ettekal, I., Sechler, C. M., \& Cortes, K. I. (2014). Grade-school children's social collaborative skills: Links with partner preference and achievement. American Educational Research Journal, 51(1), 152-183. https://doi.org/10.3102 /0002831213507327

Lapp, D., \& Moss, B. (2012). Exemplary instruction in the middle grades: Teaching that supports engagement and rigorous learning. New York: The Guilford Press.

Lavasani, M. G., Afzali, L., \& Afzali, F. (2011). Cooperative learning and social skills. Cypriot Journal of Education, 2(December 2011), 61-74. Retrieved from https://www.researchgate.net/profile/Leila _Afzali/publication/285693671_Cooperati ve_learning_and_social_skills/links/56add cd208ae43a3980e56bb/Cooperative-learni ng-and-social-skills.pdf?_sg\%5B0\%5D= 4BMlfY6lupSVS8zHQkQx0BrazT1MS1 WR6Q1yXJO_ozAOrtACxokaTiYXSd1

Lie, A. (2005). Cooperating learning: mempraktikkan cooperative learning di ruang-ruang kelas (Vol. 7386). Jakarta: Gramedia.

Lubis, M. H. (2014). Peningkatan keterampilan berbicara dengan menggunakan model pembelajaran kooperatif tipe berpikirberpasangan-berempat (. Pembelajaran Kebahasaan, 1, 1-10. Retrieved from 
http://ejournal.upi.edu/index.php/PSPBSI/ article/download/472/351

Magsino, R. M. (2014). Enhancing higher order thinking skills in a marine biology class through Problem-Based Learning. Asia Pacific Journal of Multidisciplinary Research, 2(5), 1-6. Retrieved from http://www.apjmr.com/wp-content/upload s/2014/09/APJMR-2014-2-116.pdf

Mustofa, Z., Khoiriyah, A. J., Sulistiyawati, I., Biologi, P. P., Malang, U. N., Biologifmipa, J., \& Malang, U. N. (2016). Penerapan strategi pembelajaran problem based learning melalui lesson study untuk meningkatkan keterampilan memecahkan. Jurnal Pendidikan Biologi Volume, 8(1), 32-37. Retrieved from http://journal2.um. ac.id/index.php/jpb/article/download/2275 $/ 1369$

Ouellet, K., Sabbagh, R., Bergeron, L., Mayer, S., \& St-Onge, C. (2016). Exploring residents spontaneous collaborative skills in a simulated setting context: an exploratory study on CanMEDS collaborator role. Advances in Medical Education and Practice, Volume 7, 401405. https://doi.org/10.2147/AMEP.S1016 98

Purwanto, M. N. (2014). Prinsip-prinsip teknik evaluasi pengajaran. Bandung: Remaja Rosdakarya.

Ramadani, S. D., Fauzi, A., Sukmawati, I., \& Corebima, A. D. (2015). Perbandingan potensi strategi pembelajaran cooperative script dan reciprocal teaching dalam memberdayakan keterampilan metakognitif, hasil belajar Biologi, dan retensi siswa SMA. In Proceedings of the 2nd Seminar \& Workshop Nasional Biologi, IPA, dan Pembelajarannya FMIPA UM (pp. 655-661). Malang: Biologi FMIPA UM.

Savitri, R., \& Wahyuni, S. (2013). Pengaruh penerapan model pembelajaran kooperatif tipe TPS terhadap hasil belajar ekonomi. Journal of Economic and Economic Education, 2(1), 22-27. Retrieved from http://download.portalgaruda.org/article.p $\mathrm{hp}$ ? article $=181538 \& \mathrm{val}=6300 \&$ title $=$ PEN GARUH PENERAPAN MODEL PEMBELAJARAN KOOPERATIF TIPE TPS TERHADAP HASIL BELAJAR EKONOMI

Scanniello, G., \& Erra, U. (2014). Distributed modeling of use case diagrams with a method based on think-pair-square: Results from two controlled experiments. Journal of Visual Languages and Computing, 25(4), 494-517. https://doi. org/10.1016/j.jvlc.2014.03.002

Strebe, J. D. (2013). Engaging mathematics students using cooperative learning. New York: Routledge.

Sudjana, N. (2017). Penilaian hasil proses belajar mengajar. Bandung: PT Remaja Rosdakarya.

Sukmawati, I., Ramadani, S. D., Fauzi, A., \& Corebima, A. D. (2015). Perbedaan pemberdayaan retensi antara siswa sma akademik rendah dan tinggi melalui pembelajaran cooperative script dalam pembelajaran biologi. In Proceedings of the 2nd Seminar \& Workshop Nasional Biologi, IPA, dan Pembelajarannya FMIPA UM (pp. 662-667). Malang: Biologi FMIPA UM.

Sumaryati, E., \& Sumarmo, U. (2013). Pendekatan induktif-deduktif disertai strategi think-pair-square-share untuk meningkatkan kemampuan pemahaman dan berpikir kritis serta disposisi matematis siswa SMA. Jurnal Infinity, 2(1), 26-42. https://doi.org/10.22460/ infinity.v2i1.22

Suprijono, A. (2009). Cooperative learning. Yogyakarta: Pustaka Pelajar.

Suyanto, K. E. (2008). Model-model pembelajaran. Malang: Universitas Negeri Malang.

Tahueyo, A., Martawijaya, M. A., \& Azis, A. (2013). Penerapan model kooperatif tipe think-pair-square dalam pembelajaran fisika kelas IX SMP Batara Gowa. JPF, I(2), 95-107. Retrieved from http:// journal.unismuh.ac.id/index.php/jpf/article /download/193/180

Talat, A., \& Chaudhry, H. F. (2014). The effect of PBL and 21st century skills on students' creativity and competitiveness in private schools. The Lahore Journal of Business, 2(2), 89-114. Retrieved from http://www.lahoreschoolofeconomics.edu. pk/businessjournals/V2issue2/05Talat and Chaudhry FINAL.pdf

Utami, H. W. (2014). Efektivitas pembelajaran kooperatif model think-pair-square berbantuan video pembelajaran dalam meningkatkan kreativitas siswa pada kompetensi dasar laporan keuangan. Economic Education Analysis Journal, 
Yaqin et al / JPBI (Jurnal Pendidikan Biologi Indonesia) / 4 (2) (2018) pp. 135-142

2(3), 60-67. Retrieved from https://journal.unnes.ac.id/sju/index.php/e eaj/article/download/3149/2914

Widiansyah, A. T., Indriwati, S. E., Munzil, \& Fauzi, A. (2018). I-invertebrata as an android-based learning media for molluscs, arthropods, and echinoderms identification and its influence on students' motivation. JPBI (Jurnal Pendidikan Biologi Indonesia), 4(1), 43- 52.https://doi.org/10.22219/jpbi.v4i1.5476 Zainollah. (2014). Increasing students' speaking ability and active participation in the classroom through think-pair-square. Kariman, 02(02), 117-130. Retrieved from http://ejournal.kopertais4.or.id/madu ra/index.php/kariman/article/download/76 $2 / 525$ 